\title{
An Estimation of Tax Evasion in Iran
}

\author{
Saeed Karimi Petanlar, Mohamad Taghi Gilak, Ahmad Jafari Samimi*, Alireza Aminkhaki \\ University of Mazandaran, Babolsar, Iran \\ *jafarisa@umz.ac.ir
}

\begin{abstract}
The aim of this research is to estimate the size of tax evasion between 1971 and 2007 in Iran. Among the present direct and indirect approaches, the indirect approach presented by Tanzi based on currency demand, is used to estimate the size of the underground economy, then taking the effective tax rate into consideration, the amount of the underground economy taxes. Our results show that the size of the underground economy is increasing in a long-term trend and also the ratio of the underground economy to gross domestic product has increased during the period under consideration. Our findings also indicate that tax evasion has markedly increased during the period. Therefore, policies to alleviate the tax evasion in the country should be implemented by policy makers.
\end{abstract}

Key Words: Tax evasion, Underground economy, Currency Demand Approach, Iran

\section{Introduction}

Tax evasion is a worldwide phenomenon which exists wherever there are taxes. It is not the existence of tax evasion, but its extent that is a cause of major concern for tax policy makers and tax administrators. At present, all tax evasion research can be divided into three parts: measuring the value of evaded taxes, theorizing about and estimating the structural equations that predict the partial equilibrium response of an individual to a change in preferences or incentives, and measuring the social costs of evasion. Of all these, measurement of evasion has in recent years, become a growing industry. On the other hand, measuring the size of tax evasion is useful because it gives policy makers some idea about the reliability of their policy analysis and the expected effectiveness of their policy prescriptions. However, the direct measurement of tax evasion is inherently difficult- both because its illegal nature requires secrecy and because conceptual problems make it hard to define- but the traces that tax evasion leaves can be analyzed and to some extent measured. Keeping in mind that economists and policy makers have long been interested in the connection between the underground economy ${ }^{1}$ induced by tax evasion and the public's demand for currency as well as considering the estimation of the underground economy an approach to estimate tax evasion, lead to the fact that it is impossible to neglect the literature related to the underground economy. Therefore, the later section of the research presents a brief review of theoretical fundamentals and a number of studies ever done on the subject.

Data on the extent of tax evasion or the size of the underground economy are not easily available for Iran because of their very clandestine nature and the right of fiscal secrecy that dominates Iran law. Moreover, there are different aspects of tax evasion or underground economy that need to be captured. For instance, activities in the underground economy usually involve tax evasion, and taxes could also be evaded pursuing different activities than those in the underground economy. In economics, several estimation approaches have thus been developed to "measure the immeasurable" that are usually more or less closely linked to the one or the other aspect of tax evasion ${ }^{2}$. Some of these approaches rather capture the underground economy or black activities by concentrating on the labor market, physical production or particular economic transactions. Others aim at a more comprehensive assessment of tax compliance. In this paper, the Currency Demand Approach to tax evasion is considered to measure the size of the underground economy. This paper is an attempt to estimate the size of the underground economy hence the tax evasion in Iran.

\section{Review of Literature}

The basic theoretical analysis to estimate tax evasion in the present paper, as mentioned above, is the socalled Currency Demand Approach. ${ }^{3}$ The Currency Demand Approach, which is also called an "indicator" approach, is a macroeconomic approach that uses various economic and other indicators containing information about the development of the underground economy (over time), and leaves some traces of the underground economy. This approach was first used by Cagan (1958) who calculated a correlation of the currency demand and the tax pressure (as one cause of the shadow economy) for the United States

1. In this paper, underground economy has been considered equivalent to shadow, unofficial, informal, parallel, gray and unaccounted economy.

2. Thomas (1999); Schneider \& Enste (2000); Pedersen (2003); Feld \& Larsen (2005).

3. It should be noted that there are several methods to estimate tax evasion in economics. In other words, the size of the underground economy and hence tax evasion can be estimated by direct, indirect and model approaches. Direct Approaches include Survey Approach, Tax Auditing Approach. Among indirect approaches, we can name The Physical Input Approach, The Labor Market Approach, The Discrepancy between National Expenditure and Income Statistics, The Transactions Approach, The Currency Demand Approach, The Model Approach: MIMIC \&DYMIMIC; (See Schneider and Enste, 2002); Richupan, 1986 \& Cashin, 2008). 
over the period 1919 to 1955 . Twenty years later, Guttmann (1977) used the same approach, but without any statistical procedures. Cagan's approach was further developed by Tanzi $(1980,1983)$ who econometrically estimated a currency demand function for the United States for the period 1929 to 1980, in order to calculate the underground economy. His approach assumes that underground (or hidden) transactions are undertaken in the form of cash payments, so as to leave no observable traces for the authorities. An increase in the size of the underground economy will, therefore, increase the demand for currency.

The Currency Demand Approach assumes that underground activities are the direct consequence of high taxes and that currency is used mainly for carrying out such transactions or for storing wealth accumulated from such transactions. The basic idea is to specify a demand for currency that allows one to measure the effect of tax changes on that demand. The equation is estimated and two estimates for currency holding are made, one when the tax variable is zero and the other when it is not. The difference between the two estimates of currency holding is called the "illegal money" and the difference between $\mathrm{M}_{1}$ and illegal money is taken to be the "legal money". The income velocity of money is derived by dividing GDP by legal money and the size of the underground economy is obtained by multiplying illegal money by this velocity. The amount of income tax evasion is derived by assuming that the incomes in the underground economy would have been taxed at the same average rate as income in the regular economy.

The weakness of this method is that it assumes equal velocity for legal and illegal money. Moreover, this estimation, as Tanzi (1983) himself noted, underestimates tax evasion because it only takes account of the evasion associated with currency use and the underground economy. Many forms of tax evasion exist that have nothing to do with currency usage or with underground economic activities such as claiming nonexistent exemptions or exaggerating deductions. Not does this estimate include income from criminal activities or noncriminal income that is illegal but not induced by high taxes, such as income of illegal aliens.

Empirical results of the influence of the tax burden on the shadow economy is provided in the studies of Schneider (1994, 2000, 2004, 2005) and Johnson, Kaufmann and Zoido-Lobaton (1998); they all found statistically significant evidence for the influence of taxation on the shadow economy. This strong influence of indirect and direct taxation on the shadow economy is further demonstrated by discussing empirical results in the case of Austria and the Scandinavian countries. For Austria the driving force for the shadow economy activities is the direct tax burden (including social security payments), it has the biggest influence, followed by the intensity of regulation and complexity of the tax system. A similar result has been achieved by Schneider (1986) for the Scandinavian countries (Denmark, Norway and Sweden). In all three countries various tax variables (average direct tax rate, average total tax rate (indirect and direct tax rate)) and marginal tax rates have the expected positive sign (on currency demand) and are highly statistically significant. These findings are supported by studies of Kirchgaessner $(1983,1984)$ for Germany and by Klovland (1984) for Norway and Sweden, too. In this study, an attempt will be made to investigate the influence of the direct and indirect tax burden as well as the social security payments on the shadow economy for developing, transition and highly developed countries. Hence, for the first time this influence is investigated for developing, transition and highly developed countries for the same time period and using the same estimation technique.

Kemal (2007) concluded that the impact of the underground economy is significant to the movements of the formal economy, but the impact of formal economy is insignificant in explaining the movements in the underground economy. In the long run, the underground economy and official economy are positively associated. It is estimated that the underground economy ranges between Rs 2.91 trillion and Rs 3.34 trillion (54.6 percent of GDP to 62.8 percent of GDP respectively) in 2005 and tax evasion ranges between Rs 302 billion and Rs 347 billion (5.7 percent of GDP to 6.5 percent of GDP respectively) in 2005. The underground economy and tax evasion were increasing very rapidly in the early 1980's but the rate of increase accelerated in the 1990's. It declined in 1999, but reverted to an increasing trend until 2003. It declined again in 2004 and 2005. Also, Yasmin \& Rauf (2003) conclude that the underground economy and tax evasion affects formal GDP negatively in Pakistan. A number of researchers [Shabsigh (1995); Ahmad and Ahmad (1995); Iqbal, Qureshi \& Mahmood (1998); Aslam (1998); Khalid (2002); Kemal (2003) and Yasmin \& Rauf (2003)] have tried to estimate it using Tanzi's $(1980,1983)$ monetary approach. There are several shortcomings of this approach, which lead to incomparable estimates of the underground economy and tax evasion.

\section{Model, Data, and Estimation Methodology}

Similar to Kemal $(2003,2007)$ and Aslam (1998) in this paper we have formulated our model according to the Tanzi specification as follows:

$$
\begin{gathered}
\left(\mathrm{C} / \mathrm{M}_{2}\right)_{\mathrm{t}}=\alpha_{0}+\alpha_{1}(\mathrm{~T} / \mathrm{GDP})_{\mathrm{t}}+\alpha_{2}(\mathrm{GDP} / \mathrm{N})_{\mathrm{t}}+\alpha_{3}(\mathrm{BD} / \mathrm{P})_{\mathrm{t}}+\alpha_{4}\left(\mathrm{C} / \mathrm{M}_{2}\right)_{\mathrm{t}-1}+\alpha_{5} \mathrm{D}_{\mathrm{t}}+\varepsilon_{\mathrm{t}} \\
\alpha_{1}>0, \quad \alpha_{2}<0, \quad \alpha_{3}>0, \quad \alpha_{4}>0, \quad \alpha_{5}>0
\end{gathered}
$$

Where: $\mathrm{C}$ is Currency in Circulation; $\mathrm{M}_{2}$ is Money Supply; T is Total Tax Revenues; $\mathrm{N}$ is Population, $\mathrm{BD} / \mathrm{P}$ is Real Budget Deficit; D is Dummy Variable for Revolution, $\varepsilon_{t}$ is Error term and $t$ is Time period. For each 
year predicted values of currency ratio including tax variables $\left(C / M_{2}\right)_{t}$ and without tax variables $\left(C / M_{2}\right)_{w t}$ are calculated by estimated regression equation. The difference between the two terms gives us an indication that how much currency-holding is tax induced. This difference is then multiplied by $\mathrm{M}_{2}$ to get illegal money. Subtracting illegal money from $\mathrm{M}_{1}$ gives legal money in the economy. Velocity of money (V) in the underground economy is calculated by dividing national income with legal money. Assuming that velocity of money is the same for both legal and illegal money, multiplying velocity of money by illegal money gives the underground economy. Tax evasion is calculated by multiplying the underground economy by total tax to GDP ratio. Mathematically, we can write it as:

$$
\begin{gathered}
\text { Illegal Money }(\mathrm{IM})=\left(\left(\mathrm{C} / \mathrm{M}_{2}\right)_{\mathrm{t}}-\left(\mathrm{C} / \mathrm{M}_{2}\right)_{\mathrm{wt}}\right) * \mathrm{M}_{2} \\
\text { Legal Money }(\mathrm{LM})=\mathrm{M}_{1}-\mathrm{IM} \\
\text { Velocity }(\mathrm{V})=\mathrm{GDP} / \mathrm{LM} \\
\text { Underground Economy }(\mathrm{UE})=\mathrm{IM} * \mathrm{~V} \\
\text { Tax Evasion (TE) }=\text { UE } *(\text { Total Taxes } / \mathrm{GDP})
\end{gathered}
$$

All variables are collected from the central bank of Iran (CBI) ${ }^{4}$ for the period1971- 2007. The numbers showing data are in Billion Rials and the ratios are in percent.

\section{Results}

The estimated regression results are shown in table 1. Coefficient of the tax to GDP ratio is positive and significant at 5 percent level, which implies that the higher the tax rate, the higher the currency holdings will be. Value of this coefficient is 0.689 , which shows that one percent change in the tax to GDP ratio leads to change in currency ratio by 0.689 ; GDP to population ratio has a significant negative effect on currency holdings. Real Budget deficit to $\mathrm{P}$ ratio has a significant positive effect on currency holdings;

\begin{tabular}{|c|c|c|}
\hline Variables & Coefficient & Probability \\
\hline constant & -0.028 & 0.343 \\
\hline$(\mathrm{T} / \mathrm{GDP})_{\mathrm{t}}$ & 0.689 & 0.027 \\
\hline$(\mathrm{GDP} / \mathrm{N})_{\mathrm{t}}$ & -0.021 & 0.002 \\
\hline$(\mathrm{BD} / \mathrm{P})_{\mathrm{t}}$ & 0.148 & 0.005 \\
\hline$\left(\mathrm{C} / \mathrm{M}_{2}\right)_{\mathrm{t}-1}$ & 0.743 & 0.000 \\
\hline $\mathrm{D}_{\mathrm{t}}$ & 0.022 & 0.026 \\
\hline $\mathrm{R}^{2}$ & & \\
\hline F Probability & & \\
\hline Durbin Watson & & \\
\hline
\end{tabular}
coefficient of the lag of currency holdings has a significant positive effect on currency holdings. $\mathrm{R}^{2}$ is 91.4 percent and F-statistic is also significant which implies that the explanatory variables are significantly explaining the dependent variable. DW shows no serious problem of autocorrelation.

Table 1: Result from Regression (1)

Source: Author calculations

In the table 2: TD represents direct tax, TED represents direct tax evasion, T is total tax and TE is total tax evasion. The estimations of the underground economy from equations 1 to 5 show that the underground economy is 21.4 percent of the GDP in the base year (1971). It increases to 23 percent of the GDP in 1977 but in 1980 it declines to 9.3 percent. However, between 1972 and 1997 the underground economy undergoes variations. From 1999 it rapidly increases to 46.2 percent in 2007. The estimations of tax evasion from Equation 6 show that tax evasion is 1.8 percent of GDP in the base year (1971). It increases to 2.9 percent in 1999 but declines to 1.8 percent in 2004 . However, between 2005 and 2007 tax evasion increases rapidly; it is 61413.2 in 2005 but increases to 71905.2 in 2006 and 88692.0 in 2007. Tax evasion has been compared for two states: direct tax evasions and total taxes, the ratio of each to the total collected taxes indicates that a noticeable amount of tax evasion is observed also in indirect taxes. For instance, in 2001, tax evasion comprises 24.3 percent of the total taxes but 13 percent of the indirect taxes. In other words, another portion of tax evasion is seen in indirect taxes and as is seen from table 2 , tax evasion has comprised a noticeable, varying portion of around 37.6 to 77.2 percent of direct taxes. Therefore, policy making on direct and indirect tax objectives, respectively, is of great importance.

\footnotetext{
4. www.cbi.ir
} 
Table 2: The underground Economy and Tax Evasion in Iran

\begin{tabular}{|c|c|c|c|c|c|c|c|c|c|c|c|}
\hline Obs & $\begin{array}{c}\text { UE: Bln } \\
\text { Rials }\end{array}$ & UE/GDP (\%) & $\begin{array}{l}\text { TE / } \\
\text { GDP } \\
\text { (\%) }\end{array}$ & $\begin{array}{c}\text { T/ } \\
\text { GDP } \\
\text { (\%) }\end{array}$ & $\begin{array}{c}\text { TE: Bln } \\
\text { Rials }\end{array}$ & $\begin{array}{l}\text { TE } \\
/ \mathrm{T} \\
(\%)\end{array}$ & $\begin{array}{c}\text { TED/GDP } \\
\text { (\%) }\end{array}$ & $\begin{array}{c}\text { TD } \\
/ \\
\text { GDP } \\
(\%)\end{array}$ & $\begin{array}{l}\text { TED: Bln } \\
\text { Rials }\end{array}$ & $\begin{array}{l}\text { TED } \\
/ \mathrm{T} \\
(\%)\end{array}$ & $\begin{array}{c}\text { TED/TE } \\
(\%)\end{array}$ \\
\hline 1971 & 201.7 & 21.4 & 1.8 & 8.6 & 17.3 & 21.4 & 0.7 & 3.2 & 6.5 & 8.0 & 37.6 \\
\hline 1972 & 249.7 & 21.4 & 1.8 & 8.5 & 21.2 & 21.4 & 0.7 & 3.4 & 8.4 & 8.4 & 39.6 \\
\hline 1973 & 327.7 & 19.2 & 1.5 & 7.7 & 25.2 & 19.2 & 0.6 & 3.1 & 10.2 & 7.7 & 40.5 \\
\hline 1974 & 404.5 & 13.7 & 0.7 & 5.3 & 21.5 & 13.7 & 0.3 & 2.4 & 9.9 & 6.2 & 46.0 \\
\hline 1975 & 704.0 & 21.5 & 1.8 & 8.3 & 58.3 & 21.5 & 1.0 & 4.6 & 32.7 & 12.1 & 56.1 \\
\hline 1976 & 903.4 & 20.6 & 1.6 & 7.8 & 70.5 & 20.6 & 0.9 & 4.3 & 38.6 & 11.3 & 54.8 \\
\hline 1977 & $1,175.7$ & 23.0 & 2.0 & 8.7 & 102.0 & 23.0 & 1.0 & 4.5 & 53.0 & 11.9 & 52.0 \\
\hline 1978 & 732.8 & 14.7 & 1.4 & 9.3 & 68.5 & 14.7 & 0.8 & 5.4 & 39.6 & 8.5 & 57.8 \\
\hline 1979 & 656.7 & 10.8 & 0.7 & 6.1 & 39.9 & 10.8 & 0.4 & 3.8 & 24.7 & 6.7 & 61.9 \\
\hline 1980 & 587.0 & 9.3 & 0.5 & 5.4 & 31.7 & 9.3 & 0.2 & 2.0 & 12.0 & 3.5 & 37.9 \\
\hline 1981 & 965.4 & 12.6 & 0.9 & 7.2 & 69.9 & 12.6 & 0.5 & 4.2 & 40.6 & 7.3 & 58.1 \\
\hline 1982 & $1,085.3$ & 10.8 & 0.7 & 6.1 & 66.1 & 10.8 & 0.3 & 2.9 & 31.8 & 5.2 & 48.1 \\
\hline 1983 & $1,445.5$ & 11.6 & 0.7 & 6.4 & 92.6 & 11.6 & 0.3 & 2.7 & 38.6 & 4.8 & 41.7 \\
\hline 1984 & $1,625.0$ & 12.0 & 0.8 & 6.6 & 107.7 & 12.0 & 0.4 & 3.0 & 48.5 & 5.4 & 45.0 \\
\hline 1985 & $1,956.0$ & 13.6 & 1.0 & 7.2 & 140.2 & 13.6 & 0.5 & 3.7 & 71.8 & 6.9 & 51.2 \\
\hline 1986 & $1,909.4$ & 13.0 & 0.9 & 7.0 & 133.4 & 13.0 & 0.5 & 4.0 & 75.5 & 7.4 & 56.6 \\
\hline 1987 & $1,987.7$ & 11.1 & 0.6 & 5.7 & 114.2 & 11.1 & 0.4 & 3.4 & 67.9 & 6.6 & 59.5 \\
\hline 1988 & $2,002.7$ & 9.9 & 0.5 & 4.9 & 97.8 & 9.9 & 0.3 & 3.2 & 64.0 & 6.5 & 65.4 \\
\hline 1989 & $2,649.3$ & 10.6 & 0.5 & 4.7 & 125.5 & 10.6 & 0.3 & 2.6 & 69.7 & 5.9 & 55.5 \\
\hline 1990 & $4,033.2$ & 11.7 & 0.6 & 4.9 & 198.1 & 11.7 & 0.3 & 2.7 & 108.0 & 6.4 & 54.5 \\
\hline 1991 & $7,204.6$ & 14.9 & 0.8 & 5.7 & 411.4 & 14.9 & 0.4 & 2.9 & 207.7 & 7.5 & 50.5 \\
\hline 1992 & $10,366.3$ & 16.1 & 0.9 & 5.9 & 606.8 & 16.1 & 0.5 & 3.1 & 320.0 & 8.5 & 52.7 \\
\hline 1993 & $11,651.7$ & 11.6 & 0.5 & 4.1 & 472.6 & 11.6 & 0.3 & 2.6 & 304.4 & 7.5 & 64.4 \\
\hline 1994 & $15,960.2$ & 12.1 & 0.5 & 4.2 & 665.0 & 12.1 & 0.4 & 2.9 & 466.8 & 8.5 & 70.2 \\
\hline 1995 & $23,355.7$ & 12.4 & 0.5 & 3.9 & 907.6 & 12.4 & 0.4 & 3.0 & 701.1 & 9.6 & 77.2 \\
\hline 1996 & $43,760.6$ & 17.6 & 0.9 & 5.0 & 2207.6 & 17.6 & 0.6 & 3.6 & $1,576.7$ & 12.6 & 71.4 \\
\hline 1997 & $59,712.6$ & 20.5 & 1.2 & 5.9 & 3549.7 & 20.5 & 0.8 & 3.8 & $2,262.1$ & 13.0 & 63.7 \\
\hline 1998 & $83,968.3$ & 25.6 & 1.9 & 7.6 & 6359.6 & 25.6 & 1.0 & 3.9 & $3,240.0$ & 13.0 & 50.9 \\
\hline 1999 & $137,569.1$ & 31.7 & 2.9 & 9.3 & 12752.1 & 31.7 & 1.2 & 3.8 & $5,252.1$ & 13.0 & 41.2 \\
\hline 2000 & $139,908.7$ & 24.3 & 1.5 & 6.3 & 8878.8 & 24.3 & 0.8 & 3.4 & $4,752.9$ & 13.0 & 53.5 \\
\hline 2001 & $174,327.9$ & 26.2 & 1.6 & 6.3 & 10960.4 & 26.2 & 0.9 & 3.5 & 6,029.7 & 14.4 & 55.0 \\
\hline 2002 & $227,371.6$ & 24.9 & 1.4 & 5.5 & 12586.4 & 24.9 & 0.8 & 3.1 & 6,978.4 & 13.8 & 55.4 \\
\hline 2003 & $323,863.9$ & 28.8 & 1.7 & 5.8 & 18756.1 & 28.8 & 0.8 & 2.8 & $9,229.4$ & 14.2 & 49.2 \\
\hline 2004 & $459,766.9$ & 31.6 & 1.8 & 5.8 & 26663.7 & 31.6 & 0.9 & 2.9 & $13,232.8$ & 15.7 & 49.6 \\
\hline 2005 & $846,399.4$ & 45.6 & 7.3 & 3.3 & 61413.2 & 45.6 & 2.1 & 4.5 & $38,347.0$ & 28.5 & 62.4 \\
\hline 2006 & $1,072,041.3$ & 47.4 & 6.7 & 3.2 & 71905.2 & 47.4 & 2.0 & 4.3 & $46,329.4$ & 30.6 & 64.4 \\
\hline 2007 & $1,336,444.5$ & 46.2 & 6.6 & 3.1 & 88692.0 & 46.2 & 2.0 & 4.4 & $58,414.4$ & 30.5 & 65.9 \\
\hline
\end{tabular}

Source: Author calculations

\section{Conclusion and Recommendations}

Based on the calculations and evaluations done in this research, it is concluded that throughout the years under study, in spite of the variations observed in shorter time periods, the volume of the underground economy and tax evasion as well as their share in GDP altogether had an increasing trend. In the early 1970s, owing to the rise in oil revenues and the net rise in Central Bank foreign assets, the volume of liquidity in economy increased and so did the ratio of currency to liquidity. In the 1980s, due to the outbreak of the Iraq-Iran war, governors and state executives focused on supply and production of the commodities essential for individuals and under the country conditions at that time, there was not an appropriate atmosphere for unofficial economic activities, hence liquidity was mostly spent on vital production. In the 1990s, after war, with the beginning of sate economic programs and the simultaneous advent of the young generation, the official sector was no more able to fulfill career demands, therefore, the country experienced an increase in non-production and service activities. Regarding the Iranian economy structure in which less investment is needed for non-production and service activities and such activities are more difficult to control and register, tax evasion increased during the '90s. As of 1997, additional rise in liquidity volume, together with rise in prices and capital gain becoming easier, led to an increase in tax evasion.

Taking all the above findings and facts into account, the government and monetary authorities are supposed to facilitate the conditions for production and economic activities, support domestic industries, bar intermediate dealing and service activities, allocate credits and supervise their expenditure (Most recently, private banking has considerably increased in Iran which calls for a stricter liquidity control.) and pay more attention to tax collecting administrations (The labor factor and investment in tax administrations has not increased proportional to the growth of economy size in Iran. This can be a reason for not fully reaching tax collecting goals.). As well, It is necessary that the government take appropriate actions such as attracting tax payers' trust, facilitating the conditions to boost tax morale and improving tax policy making including optimum tax rates, modern and efficient tax collection approaches as well as reducing the complexities and ambiguities of tax laws and regulations, to encourage more individuals to pay taxes hence prevent the above-mentioned trend which would be an important step toward increasing government incomes and reducing the dependence of the economy on oil revenues. 


\section{References}

Ahmed, M. \& Ahmed, Q. M. (1995). Estimation of the Black Economy of Pakistan through the Monetary Approach. The Pakistan Development Review, 34(4), 791-807.

Aslam, S. (1998). The underground Economy and Tax Evasion in Pakistan: Annual Estimates (1960-1998) and the Impact of Dollarization of the Economy. The Pakistan Development Review, 37(4), 621631.

Cagan, P. (1958). The Demand for Currency Relative to the Total Money Supply. Journal of Political Economy, 66, 303-328.

Cashin, P. (2008). Measuring the Informal Economy in Latin America and the Caribbean. IMF Working Paper, 25(4), 521-531.

Feld, L. \& Larsen, C. (2005). Black Activities in Germany in 2001 and 2004: A Comparison Based on Survey Data. The Rockwool Foundation Research Unit.

Guttman, M. (1977). The Subterranean Economy. Financial Analysts Journal, 34, 24-27.

Iqbal, Z., Qureshi, S. K. \& Mahmood, R. (1998). The Underground Economy and tax Evasion in Pakistan. Pakistan Institute of Development Economics, Research Report No. 158.

Johnson, S., Kaufmann, D. \& Zoido-Lobatón (1998). Corruption, Public Finances and the Unofficial Economy. World Bank Discussion Paper. No. 254.

Kemal, M. A. (2003). Underground Economy and Tax Evasion in Pakistan: A Critical Evaluation. Pakistan Institute of Development Economics, Research Report No. 184.

Kemal, M. A. (2007). A Fresh Assessment of the underground Economy and Tax Evasion in Pakistan: Causes, Consequences, and Linkages with the Formal Economy, PIDE Working Papers No. 13, Quaid-i-Azam University, Islamabad.

Khalid, M. (2002). Estimation of Underground Economy, Causality and Business Cycle Analysis of Pakistan. M. Phil Thesis, Department of Economics, Quaid-i-Azam University, Islamabad.

Kirchgaessner, G. (1983). Size and Development of the West German Shadow Economy, 1955- 1980. Zeitschrift für die gesamte Staatswissenschaft, 139(2), 197-214.

Kirchgaessner, G. (1984). Verfahren zur Erfassung des in der Schattenwirtschaft erarbeiteten Sozialprodukts. Allgemeines Statistisches Archive, 68(4), 378-405.

Klovland, J. (1984). Tax Evasion and the Demand for Currency in Norway and Sweden: Is there a Hidden Relationship? Scandinavian Journal of Economics, 86(4), 423-39.

Pedersen, S. (2003). The Shadow Economy in Germany, Great Britain and Scandinavia: A Measurement Based on Questionnaire Service. The Rockwell Foundation Research Unit, Copenhagen, Study No. 10.

Schneider, F. (1986). Estimating the size of the Danish shadow economy using the currency demand approach: An attempt. The Scandinavian Journal of Economics, 4, 643-668.

Schneider, F. (1994). Can the shadow economy be reduced through major tax reforms? An empirical investigation for Austria. Public Finance, 49, 137-152.

Schneider, F. (2000). The increase of the size of the shadow economy of 18 OECD-Countries: Some preliminary explanations, Paper presented at the Annual Public Choice Meeting, March 10-12, 2000, Charleston, S.C.

Schneider, F. (2004). Arbeit im Schatten: Wo Deutschlands Wirtschaft wirklich wächst., Wiesbaden, Gabler Verlag.

Schneider, F. (2005). Shadow Economies around the World: What do we really know? European Journal of Political Economy, 21(3), 598-642.

Schneider, F. \& Enste, D. (2000). Shadow Economies: Size, Causes and Consequences. The Journal of Economic Literature, 38(1), 77-114.

Schneider, F. \& Enste, D. (2002). The Shadow Economy: Theoretical Approaches, Empirical Studies, and Political Implications. Cambridge (UK): Cambridge University Press.

Shabsigh, G. (1995). The Underground Economy: Estimation, and Economic and Policy Implications-The Case of Pakistan. IMF Working Papers, 95, 101.

Tanzi, V. (1980). The underground Economy in the United States: Estimates and Implications. Banca Nazonale Del Lavoro - Rome.

Tanzi, V. (1983). The underground Economy in United States: Annual Estimates, 1930-80. IMF Staff Papers, 30(2), 283-305.

Thomas, J. (1999). Quantifying the black economy: 'measurement without theory' yet again? The Economic Journal, 109, 381-389.

Yasmin, B. \& Rauf, H. (2003). Measuring the underground Economy and its Impact on the Economy of Pakistan. The Lahore Journal of Economics, 9(2), 93-103. 